\title{
TRADUÇÃO E SISTEMA LITERÁRIO: CONTRIBUIÇÕES DE ANTONIO CANDIDO PARA OS ESTUDOS DA TRADUÇÃO
}

\author{
Germana Henriques Pereira de Sousa* \\ Universidade de Brasília
}

\begin{abstract}
Resumo: Trata-se de eleger a relação entre literatura, tradução e formação do sistema literário brasileiro, no sentido da formação de sua tradição, ou seja, estudar a importância da literatura traduzida para a formação do cânone nacional, tal como Candido apresenta em dois textos fundamentais para nosso tema: "Os primeiros baudelairianos" (2003) e "Estrutura literária e função histórica" (2000). Em ambos os textos, o autor mostra como a tradução ocupou uma posição central na formação do cânone nacional e como os tradutores participaram ativamente desse processo.

Palavras-chave: Literatura comparada e tradução. Antonio Candido. Sistema literário brasileiro.
\end{abstract}

\section{TRANSLATION AND LITERARY SYSTEM: CONTRIBUTIONS BY ANTONIO CANDIDO FOR THE TRANSLATION STUDIES}

\begin{abstract}
We intend to elect the relation between literature, translation and the formation of Brazilian literary system, towards the formation of
\end{abstract}

\footnotetext{
* Possui Doutorado em Teoria Literária pela Universidade de Brasília (2004). Bolsista de PDE/CNPq - Pós-Doutorado na Université de Rennes 2 - Haute Bretagne em Estudos da Tradução (2006-2007) e Pós-Doutorado na Pós-Graduação em Estudos da Tradução - PGET/UFSC e Université de Montréal UdeM/ Canadá (2013). Professora da Universidade de Brasília, Departamento de Línguas Estrangeiras e Tradução. Brasília, Distrito Federal, Brasil. E-mail:germanahp@gmail.com
} 
its tradition, i.e., we intend to study the importance of translated literature for the formation of national canon, as Candido presents in two fundamental texts for our theme: "Os primeiros baudelairianos" (2003) and "Estrutura Literária e função histórica" (2000). In both texts, Candido demonstrates how translation has been central in shaping the national canon and how the translators actively participated in this process.

Keywords: Comparative Literature and Translation. Antonio Candido. Brazilian Literary System.

A relação entre os trabalhos críticos e teóricos de Antonio Candido e os Estudos da Tradução pode parecer inusitada, mas apenas se a questão for vista superficialmente. De perto, quem ler com atenção a obra do crítico brasileiro poderá elencar vários pontos de contato entre seu ponto de vista acerca da literatura e da tradução e os estudos teóricos da tradução. Senão, vejamos:

- O comparatismo de Antonio Candido;

- A historiografia da literatura;

- O estudo da formação da tradição e do cânone;

- O conceito de filtro e não de influência;

- A questão da dialética local/cosmopolita na formação da literatura brasileira;

- A questão da relação entre literatura e subdesenvolvimento, que resulta em públicos restritos e na ilusão ilustrada;

- A noção de sistema literário;

- Arte de agregação e arte de segregação.

Trata-se, entre os tópicos apresentados acima, de eleger a relação entre literatura, tradução e formação do sistema literário brasileiro, no sentido da formação de sua tradição, ou seja, estudar a importância da literatura traduzida para a formação do cânone nacional, tal como Candido apresenta em dois textos fundamentais para nosso tema: "Os primeiros baudelairianos" (2003) e "Estrutura literária e função histórica” (2000). Em ambos os textos, Candido mostra como a tradução ocupou uma posição central na formação do cânone nacional e como os tradutores participaram 
ativamente desse processo. Antes, porém, vale recuperar a noção de literatura comparada e sua relação com a tradução.

Os Estudos da Tradução vêm se debruçando, desde os anos de 1970 , sobre as questões que dizem respeito ao estatuto do tradutor, seu lugar de fala no texto, que equivale ao autocomentário crítico do tradutor e sua presença no paratexto ${ }^{1}$ das obras, e que remetem às relações entre a obra e o sistema literário que a originou e o sistema literário que a recebe. A tradução e seu estudo transpõem as fronteiras da linguística para abranger um universo mais amplo que envolve a produção das obras. Susan Bassnet (2003) afirma a respeito que os Estudos da Tradução deixaram hoje de ser relegados "a uma subcategoria da Literatura Comparada" e esta, ao contrário, deveria ser considerada "um ramo dessa disciplina mais abrangente que é a dos Estudos da Tradução". Sem ir tão longe nessa discussão espinhosa dos limites entres disciplinas que, de todo modo, são afins, é preciso salientar que as relações entre língua, cultura, literatura e tradução vêm sendo discutidas há muito tempo e por várias gerações de pensadores, uma vez que o enfrentamento das diversas culturas literárias e dos diversos sistemas literários se dá de forma muito viva na tradução, pois nela, forma e conteúdo significam de modo idêntico. Goethe, por exemplo, tinha uma visão do papel do tradutor que vale a pena resgatar aqui. De fato, ele via o tradutor como um mediador de culturas que tinha importante papel a desempenhar na composição da chamada Weltliteratur, ou literatura-mundo, que teria como conceito aditivo a soma das diversas literaturas nacionais. Assim, para o poeta alemão, a tradução seria um dos instrumentos da constituição da universalidade. Segundo Oseki-Dépré (1999, p. 79), Berman lembra que, para os poetas alemães, a tradução não somente permite a ampliação das fronteiras do saber, da língua e do pensamento, como também permite a confrontação com o estrangeiro, o Outro, sem o que a humanidade fenece. Se for, pois, pela confrontação, pela comparação que o homem pode encontrar seu lugar no mundo, a tradução é o instrumento indispensável. A própria experiência de Goethe como tradutor e autor traduzido é 
reveladora de uma experiência única, a de ler sua produção literária em outra língua.

Com efeito, o fato de ter tido sua obra traduzida desde cedo nutriu a reflexão de Goethe sobre o traduzir, como atesta Berman:

\begin{abstract}
Et cet être traduit a nourri chez lui une réflexion tout à fait passionnante. Le fait qu'il ait consacré un poème - Ein Gleichnis - au fait d'avoir pu se lire dans une langue étrangère et que, dès 1799, il ait songé à procéder à une édition comparée de traductions danoise, anglaise et française d'Hermann et Dorothée, montre qu'il a vécu l'être traduit comme une expérience, et jamais semble-t-il, comme une satisfaction narcissique d'auteur. (BERMAN, 1984, p. 88, grifo do autor).
\end{abstract}

Para ele, a obra traduzida é regenerada e potencializada. Entretanto, a literatura-mundo, para Goethe, é uma utopia, que tem a ver com o idealismo alemão. A literatura-mundo entraria nesse quadro de superação dos nacionalismos, sustentando-se numa contradição: nacionalismo x universalismo. Com efeito, de acordo com Berman, para Goethe,

la traduction s'intègre dans le cadre de la Weltliteratur, de la littérature mondiale, dont le médium le plus pur pourrait bien être [...] la langue allemande. La traduction est l'un des instruments de la constitution de l'universalité. Vision qui est celle du classicisme allemand, dont il est le grand représentant avec Schiller et Humboldt. (BERMAN, 1984, p. 88).

A literatura comparada constituía um projeto generoso da intelectualidade iluminista. Segundo Hermenegildo Bastos (2007), essa "generosidade" remete aos direitos de todos os povos. Contudo, estes se esvaem com as grandes guerras da primeira metade do século XX. As nações europeias, ao se lançarem num segundo impe- 
rialismo, passam a disputar territórios em África e Ásia. O projeto de civilização universal acalentado pelos iluministas acaba aí.

A visão da tradução, como não-maniqueísta, ou como não-naturalizadora, interessaria da mesma forma aos países centrais produtores de cultura e aos países periféricos receptores de cultura? Os países periféricos, ainda que tenham uma literatura consolidada, como é o caso da nossa, não conseguem ter sua produção literária traduzida num nível que seja próximo do satisfatório, ou as obras traduzidas são as mais canônicas (e pode-se dizer que são, em geral, mal e parcamente traduzidas), ou as obras mais traduzidas são mais contemporâneas e não representam uma totalidade da produção literária nacional. ${ }^{2}$

O projeto crítico de Antonio Candido pretendeu, e ainda pretende, dar conta do fenômeno literário no país periférico que é o Brasil, para isso estuda, do ponto de vista, da literatura comparada, o processo formativo de nossa literatura.

No artigo "Literatura comparada", publicado em Recortes, Candido lembra o princípio norteador da obra Formação da literatura brasileira, publicada em 1959:

[...] estudar literatura brasileira é estudar literatura comparada porque nossa produção foi sempre tão vinculada aos exemplos externos, que insensivelmente os estudiosos efetuavam as suas análises ou elaboravam os seus juízos tomandoos como critérios de validade. (CANDIDO, 2004, p. 229).

Afirma ainda que a crítica literária produzida aqui tem como critério de base para estudar os escritores brasileiros compará-los aos autores estrangeiros. Conclui, constatando que

[...] tudo flui espontaneamente, ao correr da reflexão, como se o discurso crítico se constituísse por meio dessas aproximações reconfortantes. Uma espécie de comparatismo não intencional, elementar e ingênuo. Essa tendência dos críti- 
cos correspondia ao comportamento dos escritores, sempre inclinados a apoiar-se nos textos das literaturas matrizes. Sem falar das traduções, capítulo privilegiado nos estudos comparatistas. Lembro, ainda no tempo do Romantismo, o jogo abundante das epígrafes de autores estrangeiros contemporâneos. (CANDIDO, 2004, p. 230).

Constata assim haver em nossas terras "um ânimo comparatista, mesmo antes da instauração e divulgação da literatura comparada". De acordo com o crítico, esse ânimo comparatista se manifesta, por exemplo, no Romantismo, com o uso das epígrafes. Segundo Candido (2004, p. 230), o poeta "desliga do texto a referência e a empurra para o destaque, onde ela aparece com o nome do seu autor e a forma exata, assumindo plenamente o caráter de referência”.

Nesse breve ensaio, Candido traça o percurso de nossa vocação comparatista até à afirmação da disciplina no Brasil, na Academia; e constata que "a referência ao texto estrangeiro parece um modo constitucional da crítica brasileira" (CANDIDO, 2004, p. 232). E não poderíamos acrescentar aí que esse também seria um modo natural da crítica de tradução?

Entre os inúmeros trabalhos que cita, no percurso de 1930 até 1970, vale destacar a referência a Onédia de Carvalho Barboza, autora de uma tese (no decênio de 1950 a 1960) sobre as traduções de Byron no Brasil. E acrescenta que a Literatura Comparada firma-se no Brasil como disciplina autônoma em 1961, por iniciativa dele próprio, na Universidade de São Paulo. Porém, a disciplina somente se consolidou como oferta regular de ensino de graduação em 1969, e na pós-graduação em 1971, com Onédia Barboza. A disciplina toma vulto com a fundação da Associação Brasileira de Literatura Comparada (ABRALIC), para Candido (2004, p. 234) a “certidão de maioridade".

Candido $^{3}$ encerra o referido ensaio argumentando que o interesse e a relevância da disciplina dá-se por sermos um país "caracterizado pelo cruzamento intenso das culturas" (CANDIDO, 2004, p. 234.) 
Essa vocação comparatista determina e estrutura a Formação da literatura brasileira, obra seminal para a História da Literatura Brasileira, publicada em 1959, em que o autor articula história, teoria e crítica literárias, fundamental, segundo Wellek, para se alcançar o fito primordial, qual seja,

\begin{abstract}
[...] a descrição, interpretação e avaliação de uma obra de arte ou de qualquer conjunto de obras de arte. A Literatura Comparada que, pelo menos com seus teóricos oficiais, se absteve desta colaboração e se apegou a relações factuais, fontes, influências e intermediários e reputações como seus únicos tópicos terá que encontrar seu caminho de volta na grande corrente da crítica e dos estudos literários contemporâneos. (WELLEK, 2011, p. 117).
\end{abstract}

Na introdução à Formação, Candido afirma que estuda o processo formativo da literatura brasileira (LB) como "síntese de tendências universalistas e particularistas" (CANDIDO, 2000, p. 23), estabelecendo assim a perspectiva comparatista. Com efeito, afirma que a LB é um "galho secundário da literatura portuguesa", que, por sua vez, é "arbusto de segunda ordem no jardim das Musas" (CANDIDO, 2000, p. 9), o que de modo algum significa que a LB não tenha sido consolidada e que não seja importante, sobretudo para nós brasileiros. O que ele constata, a partir da análise dos "momentos decisivos" do processo formativo, é que a LB não poderia ser autônoma, tampouco era apenas dependente. A esse fenômeno Candido chamou de dialética local/cosmopolita, que consiste em levar em conta as literaturas matrizes sem negligenciar os aspectos locais, próprios de nosso processo formativo. A meu ver, salvo erro, essa dialética deveria fundamentar a crítica de tradução, assim como fundamentar parte da crítica literária nacional, ousaria dizer a melhor crítica literária nacional. Examinar o embate entre a literatura nacional e a literatura traduzida, considerando o jogo de forças entre a presença 
de elementos locais e estrangeiros, leva o crítico de traduções a pensar não só o estrangeiro mas a sua própria cultura.

Nessa obra, Candido narra o desejo de os brasileiros terem uma literatura. Para isso assume um ponto de vista singular, destacando o fato de que nossa literatura é "empenhada" e que o processo da formação se deu na passagem de colônia à nação. Houve no Brasil, segundo Candido (1997b, p. 12),

um duplo movimento de formação. De um lado, a visão da nova realidade que se oferecia e devia ser transformada em "temas", diferentes dos que nutriam a literatura da metrópole. Do outro lado, a necessidade de usar de maneira por vezes diferentes as "formas", adaptando os gêneros às necessidades de expressão dos sentimentos e da realidade local.

Vale acrescentar aqui que os gêneros literários viajam e se adaptam nesse processo formativo também por meio das traduções.

A literatura brasileira alcança o seu timbre próprio quando se forma no país uma tradição literária local. Os escritores brasileiros enfrentavam um desafio: traduzir a matéria local sem, contudo, abandonar a forma literária importada. A tradição local se forma quando a dialética local versus cosmopolita se estabelece dentro do sistema literário. O sistema literário, que interessa particularmente a quem estuda Tradução, é, para Candido, a tripla articulação dinâmica de um conjunto de autores, que são os produtores das obras, de um público consumidor real, os leitores, e das obras. Quando uma obra se articula com as outras obras e cria uma tradição, forma-se o sistema. Sendo assim, é somente na segunda metade do século XVIII que o tríptico autor-obra-público se estabelece no Brasil. Antes dessa data emblemática, havia apenas manifestações literárias. O sistema literário só se forma no Brasil quando também se forma um público leitor, quando produtores e leitores estão ambos empenhados com a realidade local, e isso de forma dialética, 
pois, como vimos, não era possível esquecer a contradição que estava na base de nossa formação. A configuração do sistema literário, portanto, somente acontecerá, como dissemos, na segunda metade do século XVIII, quando surgem no Brasil as Academias. O processo de configuração do sistema vai até meados do século XIX (CANDIDO, 1997a, p. 13). ${ }^{4}$

O engajamento dos intelectuais árcades com a questão da independência foi mais significativo na Arcádia Lusitana, de Minas Gerais, composta pelos escritores Cláudio Manuel da Costa, Alvarenga Peixoto e Tomás Antonio Gonzaga, os mais importantes poetas do arcadismo brasileiro, empenhados no movimento separatista da Inconfidência Mineira, em 1789.

Entretanto, tão ou mais importante que o empenho político dos poetas árcades, é a transformação da natureza local nos termos da mitologia clássica. Essa metamorfose da natureza mineira, ou tradução, melhor dizendo, como afirma Candido, em tradição clássica, compunha "uma espécie de diálogo implícito entre colônia e metrópole, barbárie e civilização" (CANDIDO, 1997a, p. 30). Essa contradição do local e do cosmopolita que aparece na poesia de Cláudio Manuel da Costa e na dos seus contemporâneos e sucessores, como os poetas românticos, gera uma acumulação literária que teve quase um século depois, em Machado de Assis, o seu melhor momento, quando o sistema literário brasileiro já se encontrava plenamente consolidado. Podemos então dizer que há no país não mais manifestações literárias isoladas, mas "atividade regular de um conjunto numeroso de escritores, exprimindo-se através de veículos que asseguram a difusão dos escritos e reconhecendo que, a despeito das influências estrangeiras normais, já podem ter como ponto de referência uma tradição local” (CANDIDO, 1997a, p. 51).

Para compreendermos melhor como se dá a convivência de vários sistemas literários num mesmo sistema, vale lembrar o importante trabalho de Itamar Even-Zohar, crítico da Escola de Tel-Aviv que desenvolveu a teoria dos polissistemas. Para Even-Zohar, o sistema literário é heterogêneo, por isso seria composto de vários sistemas literários convivendo simultaneamente. Numa comparação 
entre a noção de sistema em Antonio Candido e em Even-Zohar, Ubiratan Oliveira (1996) destaca que a noção de sistema tal como definida por Candido é também a de Even-Zohar, embora o crítico brasileiro estivesse mais preocupado, na obra Formação da literatura brasileira, em definir a continuidade literária nacional no sentido da formação da tradição, ou seja, do cânone. Todavia, Oliveira aponta que Candido não negligenciou totalmente a questão da convivência dos vários sistemas, uma vez que em Literatura e sociedade o crítico diferencia "arte de segregação" e "arte de agregação", o que poderia ser aproximado da distinção feita por Even-Zohar entre "sistema canonizado" e "sistema não-canonizado" (OLIVEIRA, 1996, p. 68-69). Em ambos os casos, a primeira forma seria aquela que procura evoluir, renovando-se, enquanto a segunda seria uma forma de reprodução de expressões já congeladas, de forma a se tornarem mais palatáveis ao público receptor. Segundo a teoria dos polissistemas, há uma comunicação entre os sistemas canonizados e não-canonizados, de sorte que aqueles podem buscar nestes elementos para a sua renovação (OLIVEIRA, 1996, p. 71).

Para Candido os elementos que estruturam a obra literária têm dois polos, comparados por ele a uma estátua do deus biface Janus: "de um lado são parte da realidade social e de outro são pura estrutura literária” (SARLO, 2001, p. 37). Assim, o trabalho do crítico consiste em saber como determinado aspecto que está no social se converte em obra literária, porém não como fotografia imediata da realidade, mas como fatura da obra. De fato, Candido preocupa-se em saber, dentro da literatura narrativa, "como é que o meio social e os traços que caracterizam a sociedade se manifestam na obra, não como tema, mas como fatura; de que modo aquilo que está na sociedade se torna uma coisa totalmente diferente, que é o texto literário" (JACKSON, 2002, p. 126-127). A esse processo entre forma literária e conteúdo social, o crítico denomina "redução estrutural" ou "processo estruturante", cujo propósito é reduzir a realidade ao "estado de estrutura literária". A análise e compreensão do processo estruturante, ou do sistema-da-obra, para usar uma expressão de Berman, é imprescindível para o tradutor e 
para o crítico, que querem evitar os engodos ocorridos em tantas traduções de obras brasileiras, como é exemplo, em certa medida, a tradução francesa de Meu tio o Iauaretê, de G. Rosa. ${ }^{5}$

$\mathrm{O}$ conceito de influência também é relativizado por Candido, que considera o instrumento "mais delicado, falível e perigoso de todo crítica, pela dificuldade em distinguir coincidência, influência e plágio" (CANDIDO, 1975, p. 37). A questão pode ganhar contornos mais complexos porque pode parecer "como transposição direta, mal assimilada, permanecendo na obra ao modo de um corpo estranho de interesse crítico secundário" e "pode, doutro lado, ser de tal modo incorporada à estrutura, que adquire um significado orgânico e perde o caráter de empréstimo; tomá-la então como influência, importa em prejuízo do seu caráter atual, e mais verdadeiro, de elemento próprio de um conjunto orgânico" (CANDIDO, 1975, p. 36). Uma obra pode filtrar tendências de outra, modificando-a, e colocando-se lado a lado desta, e não em uma posição passiva, daquela que recebe e não transforma. Por outro lado, Candido também afirma que um escritor recebe certas influências da literatura matriz de modo indireto, por exemplo, Graciliano, que leu Eça que leu Flaubert.

No caso das traduções e da contaminação da obra do escritor-tradutor pelas traduções que executa, é interessante levar em conta esse dinamismo. Muitas vezes, a crítica de tradução, no afã de descobrir influências e origens (o velho mito da originalidade), equipara, em um mesmo patamar, obras bastante diversas.

Para melhor compreendermos o lugar da tradução na formação de uma literatura como a nossa, definida por Antonio Candido como uma literatura derivada, um galho da literatura portuguesa, dependente, por sua vez, da literatura europeia, é preciso compreender como se formou o sistema literário brasileiro e qual a relação que foi aí estabelecida com a tradução.

No Brasil a tradução sempre foi importante. Foi igualmente a partir da tradução dos grandes clássicos da literatura universal que foi se formando a língua literária nacional, o público leitor brasileiro, e foi se forjando no Brasil o sistema literário brasileiro. 
Em "Estrutura literária e função histórica", Antonio Candido (2000) mostra como Basílio da Gama e Frei José de Santa Rira Durão foram considerados pelos românticos como precursores de uma tendência nacional, aquela de valorizar e destacar aspectos locais de nossa cultura, no caso, o índio. Para o Romantismo, era importante criar um passado literário para o Brasil, de forma que o país pudesse ser culturalmente distinto de Portugal, já que era diferente da metrópole com relação ao meio físico e humano:

Era preciso mostrar que tínhamos uma literatura, exprimindo características que se julgavam nacionais; [...]. Ser bom, literariamente, significava ser brasileiro; ser brasileiro significava incluir nas obras o que havia de específico do país, notadamente a paisagem e o aborígene. Por isso o indianismo aparece como timbre supremo da brasilidade, e a tarefa crítica se orientou, desde logo, para a sua busca retrospectiva, procurando sondar o passado para nele localizar os verdadeiros predecessores [...]. (CANDIDO, 2000, p. 171, grifos do autor).

Pelo que se depreende das palavras do crítico brasileiro, era preciso estabelecer uma genealogia para esse país sem tradições, que era o Brasil. Assim, Caramuru, de Durão, publicado em 1781, e cuja recepção foi à época bastante moderada, foi alçado a precursor do indianismo pelos românticos. Na origem desse aproveitamento e adequação de um mito próprio para o momento pós-independência estavam os franceses, que sublinharam em primeira mão o caráter especificamente nacional da obra. De fato, Candido relata que Ferdinand Denis, no seu Résumé de l'histoire littéraire du Portugal suivi du résumé de l'histoire littéraire du Brésil, definiu a teoria do romantismo brasileiro, alçando o Caramuru não só como paradigma de "literatura nacional", mas também para a poesia produzida no novo continente (CANDIDO, 2000, p. 185). $\mathrm{O}$ interessante desse percurso às avessas é o papel que vai desempenhar para a afirmação desse timbre nacional do Caramuru a sua 
tradução/adaptação em prosa, da obra épica para o francês, realizada em 1829, por François Eugène Garay de Monglave, como também a publicação de um romance de Gavet e Boucher, de 1830, Jakaré-Ouassu, escrito a partir de uma adequação temática do $\mathrm{Ca}$ ramuru. Segundo esse ponto de vista, Candido afirma que

\begin{abstract}
a tradução é da maior importância para elucidar o nosso tema. Esclareçamos, previamente, que ela pode ou não ter sido difundida no Brasil; que, mesmo, pode ou não ter influído diretamente, embora seja provável que sim, pois Monglave protegeu e encaminhou o grupo de reformadores literários brasileiros que, de Paris, ensaiavam renovar as nossas letras. [...] O certo, porém, é que sua versão é de natureza a ter encaminhado o Caramuru para o aproveitamento romântico, de que nos ocupamos; e isto basta para considerá-la uma etapa significativa. (CANDIDO, 2000, p. 185).
\end{abstract}

O aproveitamento do texto poético de Durão para a prosa em língua francesa, vertida por Monglave, consistiu num processo de descaracterização, conforme explicita Candido, que imprimiu ao texto um "caráter intermediário", definindo-o quanto ao gênero como um roman-poème. Essa adaptação, assim como o romance de Gavet e Boucher, Jakaré-Ouassu, e a análise feita por Denis no seu Resumé, aproximam a obra brasileira de Durão do momento romântico francês e da obra de sua figura de proa Chateaubriand, ressaltando nessas obras o choque proveniente do encontro entre as culturas europeia e autóctone, exatamente aquilo que o poema de Durão escamoteava (CANDIDO, 2000, p. 188). O caráter de paradigma alcançado pelo poema épico Caramuru para o movimento romântico brasileiro só foi possível, portanto, pelas vias tortuosas da tradução/adaptação/recepção da obra em território francês, que, por meio de uma leitura crítica e empenhada em definir uma tradução e um passado para uma literatura que ainda estava por se consolidar, conseguiu estabelecer uma nota específica para aquele momento do sistema literário brasileiro, a saber, o nacionalismo, o indianismo. 
A tradução, nesse caso, assim como a recepção crítica da obra na cultura de chegada, feita pela cultura dominante, numa via de mão dupla, em que o olhar do receptor gera na cultura de partida algo novo, inusitado, passa a se tornar elemento central do sistema literário, uma vez que é impossível desvincular a relação autor-obra-público da tradução. Dito de outro modo, a tradução de uma obra desprezada brasileira pelo processo da tradução para a língua francesa é alçada a paradigma do caráter nacional de que deveria se revestir nossa literatura durante o Romantismo, e esse fato gera, por sua vez, toda uma série de obras que passam, então, a reconhecer-se nesse passado e a reinvindicá-lo. A tradução, nesse caso, exerceu importante papel na criação, fundação de novas formas literárias nacionais, e influenciou os movimentos estéticos.

No Brasil do século XIX, segundo Candido, o gesto dos primeiros imitadores e tradutores de Baudelaire, os "primeiros baudelairianos", acabou gerando algo de novo no cenário literário nacional. A incapacidade de imitarem o modelo - Baudelaire - à perfeição gerou uma coisa nova. Candido sinaliza o fato de que na poesia dos baudelairianos da primeira safra, a partir dos anos de 1870 e início dos anos de 1880, embora sendo poetas secundários,

a presença dos textos de Baudelaire foi decisiva para definir os rumos da produção poética, traçando a fisionomia de uma fase [...]. Isso foi possível inclusive por causa de uma certa deformação, como as que em toda influência literária tornam o objeto cultural ajustado às necessidades e características do grupo que o recebe e o aproveita. (CANDIDO, 2003, p. 24-25).

Ao imitarem o modelo, ressaltaram apenas alguns aspectos da poética baudelairiana, como o satanismo ou a carne, deformando-os. Aliando agressividade erótica e radicalismo independentista, os jovens imitadores transformaram num "grande instrumento libertador esse Baudelaire unilateral ou deformado, visto por um pedaço 
(...) que favorecia uma atitude de oposição aos valores tradicionais" (CANDIDO, 2003, p. 26). Isso serviu de base para a desestabilização do Romantismo, que naquele momento já pendia para o declínio. Resumindo, o caráter imitativo dessa poesia serviu para que os poetas realistas "assimilassem algo da modernidade de Baudelaire na medida em que se inspiraram nele para afirmar o tempo presente e seus problemas, contra o refúgio no ego e na história, como tinham feito os românticos" (CANDIDO, 2003, p. 38).

$\mathrm{O}$ traço desses tradutores analisados por Antonio Candido parece colocar a tradução, tanto a obra traduzida como o processo tradutório, numa relação dialética diferente daquela estabelecida por Even-Zohar, quando define a relação de dependência entre as culturas produtoras dos países centrais e as culturas receptoras periféricas, afirmando que as obras traduzidas ocupam um lugar primário no sistema literário receptor quando influem diretamente na formação do cânone local. De fato, aqui, apesar de essas traduções terem influído na formação do cânone nacional, Candido parece demonstrar que o processo receptor das obras traduzidas e o próprio ato criador que engendra a tradução são empenhados, ainda que inconscientemente, uma vez que ocasionaram de forma inesperada e dialética a possibilidade de existência de outras obras e de outros movimentos estéticos que, embora oriundos das formas importadas dos países centrais, criaram algo novo, imprimindo às obras brasileiras um timbre próprio, embora elas continuem sendo parte de uma literatura derivada. É a esse processo que Candido nomeia a dialética do local/universal, em que os dois aspectos são parte constitutiva da obra.

Depreende-se, em suma, da leitura da história literária traçada por Candido, pelo viés comparatista, "a importância de focalizar simultaneamente a obra como realidade própria e o contexto como sistema de obras". As obras, para ele, "se articulam no tempo, de modo a se poder discernir uma certa determinação na maneira por que são produzidas e incorporadas ao patrimônio de uma civilização" (CANDIDO, 1975, p. 29).

Nos estudos descritivos da tradução, na teoria dos polissistemas, não seria essa a intenção? Estudar a tradução no contexto 
como sistema de obras e individualmente como sistema-da-obra, procurando mostrar e compreender a função que exerce uma tradução dentro de um sistema receptor, muito mais do que meramente exercer um juízo de valor, isolado. Este juízo crítico deveria, sim, advir da análise mais extensa.

\section{Notas}

1. Terminologia utilizada por Gérard Genette para designar os diversos textos que acompanham e cercam a obra. Trata-se da apresentação externa do livro, do nome do autor, título, subtítulo, da quarta-capa; interna: dedicatórias, epígrafes, prefácios, pósfácios, intertítulos, notas de rodapé, glossário. Ao conjunto desses textos que se situam em torno do texto, Genette chama de peritexto. $\mathrm{O}$ epitexto é constituído por todos esses textos que estão em torno do texto, mas a uma distância "mais prudente", e que se situam de modo geral fora do livro: trata-se das mensagens que se encontram num suporte midiático (entrevistas) ou numa comunicação privada (diários, correspondência, outros). Cf. GENETTE, 1987.

2. Consultar a respeito SCHWARZ, 2006; TORRES, 2004; e MARTINS, 2009.

3. A vocação comparatista de Candido é estudada por Tânia Franco Carvalhal, pela contribuição do crítico à ABRALIC e à fundação da disciplina no Brasil: CARVALHAL, 1988. E, também, por BETTENCOURT, 1996.

4. Essas sociedades literárias são importantes porque reuniam intelectuais de todo o país com preocupações e desejos comuns, quais sejam, o maior conhecimento das questões nacionais, a identidade nacional, mas também o conhecimento da fauna e da flora, a modernização da educação e do governo. Enfim, a decadência do barroco e a influência do neoclassicismo europeu fizeram com que o Arcadismo no Brasil fosse uma fase de amadurecimento da vida literária e política nacional, num processo que questionava o estatuto do Brasil como colônia e aspirava à independência nacional. De fato, conforme Candido, "esse é um momento de amadurecimento para todo o Brasil, que finalmente adquire um contorno geo- 
gráfico bem próximo do que tem hoje (...). Esse amadurecimento se reflete na quantidade de homens cultos que atuaram aqui e na Metrópole (...) formando o primeiro grande conjunto de brasileiros capazes de ombrear com os naturais de Portugal" (CANDIDO, 1997a, p. 28).

5. Tal como demonstra em sua análise das Memórias de um Sargento de Milícias, o processo estruturante da obra é a dialética da ordem e da desordem. O sucesso da empreitada de Manuel Antonio de Almeida deve-se não apenas a seu caráter documental, mas à resolução estética da obra. A dialética da ordem e da desordem atravessa todos os elementos constituintes da obra, personagens, enredo etc., de modo que escolher um dos polos fundadores da obra seria reduzi-la a apenas um de seus aspectos constituintes. Para Candido, a função total, ou seja, a junção da função social (que incluiria elementos que, independentemente de sua vontade, o autor capta e que têm a ver com a recepção da obra) e da função ideológica (o objetivo consciente do escritor, a sua intencionalidade), "é o que faz de um texto um texto literário" (SARLO, 2001, p. 40). A função total, propriamente estética, é a que confere universalidade à obra literária, uma vez que, de acordo com Candido, "uma obra somente pode ser esteticamente válida se, além de incorporar uma função social adequada dos elementos da realidade, logra pelo menos algo da universalidade própria da função total" (SARLO, 2001, p. 41).

\section{Referências}

BASSNETT, Susan. Estudos de Tradução. Fundamentos de uma disciplina. Trad. Viviana de Pádua Figueiredo. Lisboa: Fundação Calouste Gulbenkian, 2003.

BASTOS, Hermenegildo. O que vem a ser representação literária em situação colonial. Revista Intercâmbio dos Congressos de Humanidades, 2007. Disponível em: <http://www.onda.eti.br/revistaintercambio/conteudo/arquivos/1351. doc >. Acesso em: 09 ago. 2013.

BERMAN, L'épreuve de l'étranger. Paris: Gallimard, 1984. 
BITTENCOURT, Gilda Neves. Literatura comparada no Brasil. Revista Organon - Literatura Comparada: Diálogos e Tendências, v. 10, n. 24, 1996.

CANDIDO, Antonio. Formação da literatura brasileira (momentos decisivos). 5. ed. Belo Horizonte: Itatiaia; São Paulo: Edusp, 1975. v. 1.

CANDIDO, Antonio. Formação da literatura brasileira (momentos decisivos). Belo Horizonte/Rio de Janeiro: Editora Itatiaia Limitada, 1997a. 2 volumes. $1^{\circ}$. Volume: 1750-1836.

CANDIDO, Antonio. Iniciação à literatura brasileira. 3. ed. São Paulo: Humanitas, 1997b.

CANDIDO, Antonio. Estrutura literária e função histórica. In: Literatura e sociedade. 8.ed. São Paulo: T. A. Queiroz, 2000. p. 169-192.

CANDIDO, Antonio. Literatura comparada. In: . Recortes. 3. ed. Ouro sobre Azul, 2004. p. 211-215.

CARVALHAL, Tania Franco. Antonio Candido e a Literatura Comparada no Brasil. In: ANAIS DO I CONGRESSO ABRALIC. Porto Alegre: UFRGS, 1988, v. 1, p. 13-16.

EVEN-ZOHAR, Itamar. Polysystem Theory. Poetics Today, v. I, n. 1-2, p. $287-$ 310, 1972. Tradução “Teoria del Polisistema”, realizada por Ricardo Bermudez Otero, publicada em Poetics Today, v. 11, n. 1, p. 9-26, primavera 1990. Disponível em: < http://www.tau.ac.il/ itamarez. Acesso em: 15 jun 2013

GENETTE, Gérard. Seuils. Paris: Éditions du Seuil, 1987.

JACKSON, Luiz Carlos. Entrevista concedida a em 06/06/1996. In: CANDIDO, Antonio A tradição esquecida. Os parceiros do Rio Bonito e a sociologia de Antonio Candido. Belo Horizonte: Editora UFMG; São Paulo: Fapesp, 2002. p. 126-148.

MARTINS, M. O papel da patronagem na difusão da literatura brasileira. In: GUERINI, Andréia; TORRES, Marie-Hélène C.; COSTA, Walter Carlos (Org.). Literatura traduzida \& Literatura nacional. Rio de Janeiro: 7Letras, 2009. 
OLIVEIRA, Ubiratan. O polissistema literário identificado por Even-Zohar. Literatura Comparada: diálogos e tendências. Organon, Revista do Instituto de Letras da UFGRS, v. 10, n. 24, 1996.

OSEKI-DEPRÉ, Inês. Théories et pratiques de la traduction littéraire. Paris: Armand Colin, 1999. (Collection: U Lettres)

SARLO, Beatriz. Antonio Candido: para una crítica latinoamericana. Antonio Candido y los estudios latinoamericanos. Edición de Raúl Antelo, Série Críticas. Pittsburgh: Universidad de Pittsburgh, 2001. Entrevista de Antonio Candido concedida a Beatriz Sarlo em 1980.

SCHWARZ, Roberto. Leituras em competição. Novos Estudos CEBRAP, São Paulo, n. 75, jul. 2006. Disponível em: < http://www.scielo.br/scielo. php? script $=$ sci_arttext\&pid $=$ S0101-33002006000200005\&lng $=$ en\&nrm $=\mathrm{i}$ so >. Acesso em: 12 ago. 2013.

TORRES, M.-H. Variations sur l'étranger dans les lettres, cent ans de traductions françaises des lettres brésiliennes. Arras: Artois Presses Université, 2004.

WELLEK, René. A crise da literatura comparada. Trad. Maria Lúcia Rocha-Coutinho. In: COTINHO, Eduardo F.; CARVALHAL, Tania Franco (Org.). Literatura Comparada: textos fundadores. Rio de Janeiro: Rocco, 2011.

Recebido em: 12/09/2014 Aceito em: 07/12/2014 